\title{
Doppler ultrasonography versus venography in the detection of deep vein thrombosis in patients with pulmonary embolism
}

\author{
Ömer Özbudak · Ismail Eroğulları · Candan Öğüsş · \\ Aykut Çilli · Mehtap Türkay · Tülay Özdemir
}

Published online: 14 April 2007

(C) Springer Science+Business Media, LLC 2007

Erratum to: J Thromb Thrombolysis 21(2): 159-162

DOI 10.1007/s11239-006-5207-3

The authors have requested that errors in the Materials and Methods section be corrected to read as follows:

First paragraph, fifth sentence is replaced with:

V/Q scintigraphies were classified into three subgroups on the basis of the PIOPED criteria: high, medium and low probability.

Second paragraph is replaced with:

DVT diagnosis

Patients with the diagnosis of pulmonary emboli were evaluated by Doppler USG to investigate a possible DVT. Doppler USG was performed to initially Doppler negative patients again at least seven days later than the first evaluation. Additionally, all patients underwent venography.

The online version of the original article can be found at http://dx.doi.org/10.1007/s11239-006-5207-3

Ö. Özbudak $(\bowtie) \cdot$ I. Eroğulları · C. Öğüş ·

A. Çilli · M. Türkay · T. Özdemir

Akdeniz Üniversitesi Týp Fakültesi, Göðüs Hastalýklarý

Anabilim Dalý, Antalya 0070, Turkey

e-mail: ozbuduk@akdeniz.edu.tr 